\title{
Test of Linkage between Governance Style and National Economic Indices
}

\author{
Sharlywest Uwabor Eboigbe ${ }^{1} \&$ Innocent Okwuosa ${ }^{2}$ \\ ${ }^{1}$ Department of Banking and Finance, Faculty of Management Sciences, University of Benin, Benin City, Nigeria \\ ${ }^{2}$ Hertfordshire Business School, University of Hertfordshire, Hatfield, UK \\ Correspondence: Sharlywest Uwabor Eboigbe, Ph.D., Department of Banking and Finance, Faculty of Management \\ Sciences, University of Benin, Benin City, Nigeria. Tel: 234-805-661-1838.
}

Received: Decemebr 15, 2017

Accepted: January 6, 2018

Online Published: January 25, 2018

doi:10.5430/ijfr.v9n1p226

URL: https://doi.org/10.5430/ijfr.v9n1p226

\begin{abstract}
The relationship between the deliberate reinvention of the wheel, for macroeconomic indices such as interest rate, inflation, exchange rate, stock prices, index of industrial output within the electoral windows and the political parties' (incumbent and opposition) ideology is the focus of this study. Monthly macroeconomic data for UK, USA, Japan, China, Hong Kong, Egypt, South Africa, Brazil, Nigeria, France and Germany from Morgan Stanley Capital International (MSCI) as well as World Bank for the period of 2000-2015 were used in the study. Employing majorly, the dynamic Genaralized Method of Moment (GMM) estimation technique, the study reveals that the coefficients of partisanship effects have the same negative signs and is significant for all the countries except Nigeria and Egypt. Also, the coefficients are similar in terms of size (US and China). Hence, the results show that party orientation does have significant impact on stock market returns of the selected countries with greater impact on Nigeria and Egypt. Strengthening the various regulatory agencies in charge of these macroeconomic policies is recommended to avoid this uncessary manoeuvring in governance. We are of the view that automation of capital markets activities will reduce the chances of manipulating capital market economic data.
\end{abstract}

Keywords: election, macro economic indices, monetary policy, capital market efficiency, partisanship, governance style

JEL Classification: D72, E52, G14, P16, H11

\section{Introduction}

Partisan theory of business cycle is the alteration in the fiscal and monetary policies that exist between political parties and general economic indices within their duration in office (Franzese, 2002). Where the opposition government aims to boost the aggregate real economic activity using full employment as a critical factor, the incumbent usually focuses on aggressive reduction of inflation rate (Koksal amd Aliskan (2012). Each of these goals has multiplier effect on the wellness of the citizenry. Governments' alteration of its discretionary power to levy taxes and charges during electoral window, deliberate alteration of market-enhancing regulations and future policies affecting the business cycle lend credence to the interplay of sub-components in political economy.

Since politics is the fulcrum upon which the economy revolves, stakeholders ought to monitor politically-motivated alteration of economic data and its antecedent risks so as to determine the impact on the welfare of citizens. Considering the linkage between elections and the economic wellbeing of domestic firms, governance culture and trade, it is argued that the potential for political conflict during electoral window has significant negative effects on cross-border trading. The unabated civil crises in some countries like Central African Republic, Democratic Republic of Congo, Egypt, Somalia, Syria, Pakistan, Israel-Palestine conflicts are credible reference points, even where these did not arise from electoral windows. This hinders business transactions including financial assets and sovereign bonds. When foreign portfolio investments are distorted, the spill over effect on the national economic parameters are enormous. This can result in reduced gross domestic product and high capital flights powered by divestments of foreign portfolios (Blomberg and Hess, 2003, Acemoglu and Yared, 2010).

Partisanship and governance style affect stock market movement. Hence it is a veritable predicting economic tool for GDP growth, trade balances, and inflation as well as unemployment rates. The reverse market-to-political policies 
influence through lobbyism, campaign contributions to particular party candidates justify these circular relationships to firm-specific stock price effects (Knight, 2007; Siokis and Kapopoulos, 2007; Mattozzi, 2008; Brunner, 2009; Wong and McAleer, 2009; Gerber, Huber and Washington, 2009; and Furio and Pardo, 2010, 2012). Therefore, political outcome of an election affects corporate performance as a result of the pattern of government expenditure, tax policies, consumption patterns and investment. Inflation-unemployment interplay as well as other key macroeconomic parameters are at the mercy of the ruling party possibly due to the fusion of monetary and fiscal government agencies.

Accordingly, Oehler, Walker and Wendt, (2011) observe that through sector-specific government policies, stock market performance may be distortorted prior to an election window. They conclude that party's ideology has a way of impacting significantly on market returns. This they supported using the cumulative abnormal returns from the capital market. Implying therefore that presidents and their political parties' ideology is instrumental to national economic health. Where economic fundamentals are at variance with realities, the traditional political economy models determine market operation. Empirical evidence in support of no significant impact of partisanship on inflation may hold in the case of national monetary policy of a single currency market like the European Union currency. Here the regional regulatory agency's (European central bank) objective of sustainable price stability comes to the fore (He, Lin, Wu \& Dufrene, (2009). This reduces the probability of volatility as winner of the election becomes clearer (Goodell \& Bodey, 2012).

Opportunistic opposition governments certainly choose to fortify strategies that are against inflation in other to win voters sympathy in the course of election years. At the same time incumbents which implemented contrary policy of reducing inflation might employ monetary expansion towards the end of their electoral mandate. This is done so as to win elections in a period of aggregate economic growth. The more competitive elections are, the higher the tendency to create political business cycle where opportunistic strategy to stimulate economic expansion by sustaining avoidable cost for social welfare are implemented (Krause, 2005).

Arguably, politics and economics appear to be two dependent fields of human endeavour that cannot be separated within the confine of political business cycles. Political business cycles represent unending cycles in macroeconomic variables with its origin from electoral activities. The trade-off between inflation and unemployment is assumed to thrive on myopic and retrospective views of voters, hence, opportunistic political business cycle model envisages governments' willingness to shoot up employment figures just before elections through various operational policies (Garcia-Sanchez, Mordan and Cuadrado-Ballesteros, 2014; Vasquez-Ruiz, Rivas and Daz, 2014). This enables them to accept higher than optimal inflation rate. Opportunistic behaviour takes effect in pre-election years, while the partisan behaviour is manifests between different parties' tenure in office (Klomp and de Haan, 2013; Foremny and Riedel, 2014; Shelton, 2014). Therefore, there exist a timing difference in the political business cycle theory.

According to Karakas (2014), political business cycles manifest in all countries regardless of stages of development, governance structures and robust institutional framework. Political manipulation using electoral outcomes confirms the invisible determinant of macroeconomic variables (real per capita GNP, inflation, taxes and unemployment). This is through the exploitation of voters irrationality evidenced by short memories. This manipulation of policy tools by incumbent politicians through the stimulation of the economy prior to election to enhance re-election chances could be expansionary or contractionary policies. This they do in connivance with various government institutional agencies.

Interestingly, such deliberate manipulation might result in unpleasant consequences on the long-run, such as hyperinflation, growth without corresponding development, low rate of savings, unfavourable trade balance among others. Reversal of actions such as raising taxes, interest rate, getting to its ceiling without recourse to economic fundamental and market forces as well as heightened austerity measures present a big challenge to voters.

Rakic, Stanojevic and Rađenovic, (2015) submits that inflation and unemployment in the pre-election window is determined by political interests with the ultimate reversal in post-election period to its level before the electoral events. For example, people engaged in illegal activities such as prostitution, drug-dealing, banned gambling, smuggling among others may be classified as employed during elction window only to be classified as unemployed after election. We argue that state rules to stem the above vices are ignored before elections so as to give the nation a high aggregate employment status. But these are not tolerated as soon as elections are over. Politicians demand for re-election without considering the national economic stability and social security of citizens lends credence to their use of expansionary monetary policy before the elections so as to reduce unemployment (Akhmedov \& Zhuravskaya, 2004; Drazen \& Elsava, 2005; Veiga \& Veiga, 2007; Findley, 2015). This expansionary monetary policy brings to the fore the relatedness of political business cycles and political budget cycles. This suggests that period of low unemployment with low inflation rate increase the probability of re-election and reverses shortly as inflation adjusts. 
Drazen (2000) opines that to cushion the inflation-unemployment puzzle (trade-off between the inflation rate and unemployment), Central banks should accommodate this political strategy from governments to avert sharp rise in interest rates at the times of re-election. The absence of a long-run trade-off with reference to inflation and unemployment thus tends to push the unemployment rate below some tolerable extent with accelerated inflation. We are of the opinion that the absence of long-run neutrality of inflation and growth in money supply is an axiom with wider acceptance if general equilibrium in the economic systems is to be attained.

Therefore, unemployment, inflation, money supply, capital market, real interest rates and other macroeconomic indices have effect on nation's social and economic welfare. The influence of expansionary monetary policy on interest rates depicts an inverse relationship. This agrees with the postulations that monetary regulation is dependent on political manipulations (Leertouwer \& Maier, 2001\&2002). Haynes and Stone (1989) find a four-year cycle on GNP, unemployment, GDP and inflation, overlapping with election time. Based on the foregoing there is therefore the need to examine the deliberate reinvention of the wheel, for macroeconomic indices such as interest rate, inflation, exchange rate, index of industrial output, stock prices among others by the different political party ideology, which is the aim of this study.

\section{Review of Related Literature}

The reaction of inflation and output gap driven by increased unemployment at any period has a multiplying negative effect on the general economy. The pre-election period political objectives of incumbent parties ought to unite with opposition parties. Increase in public sector investments, expenditure on employees' compensation, subsidies, unemployment benefit and social welfare prior to election window suggest a bubble. The imminent reversal afterwards shows that the players are not interested in the citizens' wellness rather their inordinate ambition (Eboigbe, 2016).

Government deliberate increase in tax revenues before and after elections to fund increased expenditures and manipulated fiscal policies culminates in income redistributive manoeuvring. This is done through making limited businesses and individual to go through recession. This recession immediately translates into the national health evidenced in GDP and other indicators after the events (Kachelein, Imami \& Lami, 2008). Wolfers and Zitzewitz (2004), find that increase in unemployment rate translates to reduction of votes received by the incumbent party in an election. Rakic, Stanojevic and Radjenovic, (2015) confirms the existence of inflation and unemployment in a pre and post-election period resulting from deliberate adjustment due to political interests with the likelihood of reversal to their original level. Tutar and Tansel (2000), Kuzu (2001), Asutay (2004) study reveals budget deficits relationship with electoral cycles in Turkey. This manifested when the monthly and quarterly data were used but but vanishes when annualized data were used indicating that elections is of no relevance on annual data.

Capital markets activities as well as general economic development thrives on volume (breadth and depth), confidence and liquidity fuelled by increased cash flows. Liquidity problems in the financial markets accompanied by low productivity tends to reinforce credit constraint shock, with an associated effect of recession which is highly detrimental to the economic health. Inflation-targeting central banks seems to put more emphasis on employment and wage changes so as to prevent surge in wage inflation to forestall general price inflation. The differences in economic conditions of members of various regional political and economic groupings manifests in various country's business cycle dynamics and reactions to monetary policy framework on the basis of national macroeconomic data (Overman \& Puga 2002; Wall \& Zoega, 2002; Fang \& Silos, 2012). Unemployment is a cost to the workers, employer and the nation. As workers' purchasing power diminishes, employers' experiences low productivity with lower market share and reduced turnover while the national economic performance will experience lower GDP. Rise and fall in capital market indices are also not excluded (Eboigbe, 2016).

This politically motivated manipulation of economic data leads temporarirly to biased redistribution of wealth. At other times it may be on form of interference with market forces which in turn hampers competition culminating in price manipulation. Andrikopoulos, Ioannis and Prodromidis, (2004), Sieg and Batool (2012) confirm that unemployment tends to be lower in pre-election periods and surges immediately after elections conceivably due to politically inspired employment patterns. They argue further that inflation drop in pre-election may also not be unconnected with pre-electoral price regulatory mechanism and increment in public borrowings for deficit budget. Based on the forgoing arguments and evidences, we hypothesized therefore that:

The ideology of Political party in power has significant directional relationship with macroeconomic variables within the electoral cycles of countries. 


\section{Methodology, Econometric Fundamentals and Model Specification}

A multiple regression model which incorporates dummy variables to capture the different parties in power is used to address the relationship between partisanship/governance style and market returns, which is one of the objectives of this study. Following the pioneering work of Santa-Clara and Valkanov (2003) and the traditional event study models, the following model is specified:

$$
r_{t+1}=\alpha_{l} l w_{t}+\alpha_{2} r w_{t}+\gamma r_{t}+u_{t+1}
$$

Where $r_{t+l}$ is stock returns; $l w$ is the dummy that takes 1 when a leftist-oriented political party is in power, and otherwise; $r w$ is the dummy variable that takes the value of 1 when a rightist-oriented party is in power and otherwise. When equation (1) is lagged one period with respect to returns $r$, it becomes:

$$
r_{t}=\alpha_{l} l w_{t}+\alpha_{2} r w_{t}+\gamma r_{t-1}+u_{t}
$$

In order to avoid omitted variable difficulties in the model, an index of world stock prices is built into the model to become:

$$
r_{t}=\alpha_{1} l w_{t}+\alpha_{2} r w_{t}+\delta W I_{t}+\gamma r_{t-1}+u_{t+1}
$$

Where WI is the index of world stock market wherein we considered MSCI data for the samples of essence due to its universal credibility for its independent of national agencies.

From the model, the signs of $\alpha_{1}$ or $\alpha_{2}$ reflect the effect of the party orientation on stock market. A positive coefficient for any of the party dummy implies that the party pursues a pro-output expansion and employment growth policy which will lead to boom and increase in the stock market returns. While a negative coefficient implies that the particular political party pursues a policy that strangulates output growth (perhaps by fighting inflation) which leads to a drop in stock market performance and returns.

The panel data estimation technique was adopted since economic variables from different economic blocks are used in the estimation (see Woodridge, 2001), wherein the longitudinal research design is deemed imperative. Using the Ordinary Least Squares (OLS) and the dynamic system GMM (generalized method of moment) estimation techniques, the problem of heterogeneity and simultaneity that may exist between policy instrument and output gap or inflation over time is addressed. The data stream for this study were sourced from various international regulatory and rating agencies such as Morgan Stanley Capital International $(M S C I)$ which was designed to measure equity market performance, the World Bank and the Trading Economics.

The selected countries of interest here are independent democratic countries of the global community. Where the sampled size includes the United Kingdom, United States of America, Japan, China, Hong Kong as well as Egypt. Also on the list are Republic of South Africa, Brazil, Nigeria, France and Germany. This is with a view to revealing globally the effect of political events on capital market and national economic indices. A critical look at the list reveals that the countries have stable democratic culture as well as leaders in their respective economic and sub-regional groupings. The sampled countries are also in the first forty largest economy hence findings therefrom can substantiate globally acceptable economic and investment decision theories. Data used covered the period 2000-2015 for the various election dated.

The following are the various countries politically-related events dates for the countries as indicated with the political parties in brackets. Republic of South Africa $-14^{\text {th }}$ April 2004 (ANC), $22^{\text {nd }}$ April 2009 (ANC) and $07^{\text {th }}$ May 2014 (ANC). Nigeria: $19^{\text {th }}$ April 2003 (PDP), $21^{\text {st }}$ April 2007 (PDP), 16 ${ }^{\text {th }}$ April 2011 (PDP) and $28^{\text {th }}$ march 2015 (APC). Egypt: 25 ${ }^{\text {th }}$ May 2005 (Political Referendum), $26^{\text {th }}$ march 2007 (Political Referendum), $19^{\text {th }}$ march 2011(Political Referendum), 24 ${ }^{\text {th }}$ May 2012 (Election/Freedom Justice Party), $03^{\text {rd }}$ July 2013 (Coup) and $28^{\text {th }}$ May 2014 (Independent). United Kingdom: 07 $7^{\text {th }}$ May 2000 (LP), $05^{\text {th }}$ May 2005 (LP), $06^{\text {th }}$ May 2010 (CP/LP) and $07^{\text {th }}$ May 2015 (CP). United State of America: $07^{\text {th }}$ November 2000 (Republican), 02 ${ }^{\text {nd }}$ November 2004 (Republican), $04^{\text {th }}$ November 2008 (Democrat) and $06^{\text {th }}$ November 2012(Democrat). China: $20^{\text {th }}$ march 2004 (DP), $22^{\text {nd }}$ march 2008 (CNP), $14^{\text {th }}$ march 2012 (CNP) and $16^{\text {th }}$ march 2016 (DP). Japan: $11^{\text {th }}$ September 2005(LDP), 30 ${ }^{\text {th }}$ August 2009(LDP), $16^{\text {th }}$ December 2012(LDP) and $14^{\text {th }}$ December 2014(LDP). Brazil: $06^{\text {th }}$ October 2002(PDT), $01^{\text {st }}$ October 2005 (PDT), $3^{\text {rd }} \& 31^{\text {st }}$ October 2010(PDT) and $05^{\text {th }}$ October 2014(PDT). Hong Kong: $28^{\text {th }}$ February 2002(Non-partisanship), $16^{\text {th }}$ June 2005(Non-partisanship), $25^{\text {th }}$ march 2007(Non-partisanship) and $25^{\text {th }}$ march 2012(Non-partisanship). Germany: 22nd September 2002(SDP), $18^{\text {th }}$ September 2005(CDU), $27^{\text {th }}$ September 2009(CDU) and $22^{\text {nd }}$ September 2013(CDU). France: $5^{\text {th }}-6^{\text {th }}$ May 2002(RR), $5^{\text {th }}-6^{\text {th }}$ May 2007(UPM) and $5^{\text {th }}-6^{\text {th }}$ May 2012(SP). 


\section{Result Presentation and Discussion of Findings}

Here we report the descriptive and empirical analysis of the macroeconomic variables used in the study and their respective reactions to different political orientations within different time.

Table 1a. Descriptive statistics of macroeconomic data

\begin{tabular}{|c|c|c|c|c|c|c|c|c|}
\hline \multirow{2}{*}{ Country } & \multicolumn{2}{|c|}{3 months before } & \multicolumn{2}{|c|}{12 months before } & \multicolumn{2}{|c|}{3 months after } & \multicolumn{2}{|c|}{12 months after } \\
\hline & Mean & Std & Mean & Std & Mean & Std & Mean & Std \\
\hline \multicolumn{9}{|c|}{ For interest rate } \\
\hline$U K$ & 1.61 & 1.85 & 1.78 & 1.88 & 1.92 & 2.13 & 1.87 & 1.97 \\
\hline$U S$ & 2.92 & 6.28 & 1.53 & 2.86 & 1.24 & 0.79 & 1.40 & 1.24 \\
\hline Brazil & 12.58 & 3.26 & 14.28 & 4.68 & 13.64 & 4.61 & 12.47 & 4.73 \\
\hline Egypt & 8.90 & 0.74 & 9.07 & 6.34 & 9.08 & 0.76 & 9.02 & 0.60 \\
\hline S. Africa & 7.25 & 1.38 & 4.84 & 3.34 & 8.00 & 2.22 & 9.03 & 3.12 \\
\hline Nigeria & 9.22 & 3.12 & 10.65 & 4.31 & 9.39 & 2.90 & 9.15 & 2.95 \\
\hline H Kong & 3.94 & 2.65 & 4.28 & 1.20 & 3.58 & 2.47 & 3.45 & 2.47 \\
\hline China & 5.87 & 2.36 & 6.11 & 2.65 & 6.43 & 0.93 & 6.22 & 0.74 \\
\hline Japan & 0.03 & 0.05 & 0.04 & 0.41 & 0.02 & 0.05 & 0.05 & 0.11 \\
\hline France & 2.83 & 0.72 & 2.70 & 0.98 & 2.61 & 1.22 & 2.81 & 1.45 \\
\hline Germany & 10.58 & 12.56 & 3.17 & 0.91 & 2.00 & 0.00 & 1.65 & 0.58 \\
\hline \multicolumn{9}{|c|}{ For output growth } \\
\hline$U K$ & 0.72 & 2.17 & -1.15 & 9.34 & 2.01 & 1.75 & 1.48 & 8.50 \\
\hline US & -0.43 & 4.64 & 1.26 & 9.03 & -2.64 & 7.60 & -2.26 & 8.61 \\
\hline Brazil & 2.01 & 6.57 & 5.59 & 8.62 & 1.59 & 4.89 & 1.62 & 2.00 \\
\hline Egypt & 5.71 & 11.79 & -1.84 & 9.15 & 1.58 & 18.24 & 4.54 & 2.71 \\
\hline S. Africa & -4.03 & 8.55 & -1.55 & 8.01 & -5.21 & 9.49 & 2.62 & 1.43 \\
\hline Nigeria & 1.37 & 2.69 & 1.72 & 7.26 & 0.44 & 0.59 & -0.82 & 1.84 \\
\hline H Kong & -0.80 & 1.36 & 1.86 & 7.27 & 2.50 & 6.92 & 0.62 & 0.51 \\
\hline China & 14.41 & 4.72 & 15.73 & 8.65 & 12.41 & 5.16 & 12.11 & 1.14 \\
\hline Japan & -10.22 & 11.34 & -5.78 & 10.40 & -6.02 & 7.18 & 3.64 & 0.17 \\
\hline France & -0.74 & 1.91 & 0.14 & 9.40 & 0.18 & 2.60 & -1.01 & 0.42 \\
\hline Germany & -4.32 & 9.28 & -4.39 & 9.43 & -0.57 & 6.15 & 4.18 & 0.39 \\
\hline \multicolumn{9}{|c|}{ For inflation } \\
\hline$U K$ & 1.72 & 1.49 & 1.60 & 0.90 & 1.94 & 1.47 & 2.02 & 1.52 \\
\hline$U S$ & 3.14 & 1.29 & 3.07 & 1.17 & 1.98 & 1.97 & 1.53 & 1.96 \\
\hline Brazil & 5.80 & 0.93 & 5.91 & 1.30 & 5.96 & 0.71 & 6.52 & 5.36 \\
\hline Egypt & 9.66 & 3.08 & 8.84 & 1.99 & 8.27 & 3.43 & 8.46 & 7.25 \\
\hline S. Africa & 4.92 & 3.55 & 6.39 & 3.35 & 5.39 & 2.43 & 3.37 & 3.82 \\
\hline Nigeria & 8.93 & 2.51 & 9.46 & 3.05 & 7.93 & 3.29 & 8.77 & 4.93 \\
\hline H Kong & 2.63 & 2.26 & 2.68 & 2.28 & 2.59 & 1.49 & 2.51 & 1.37 \\
\hline China & 4.73 & 2.21 & 4.16 & 2.28 & 4.50 & 2.96 & 3.33 & 3.04 \\
\hline Japan & -0.91 & 0.88 & -0.17 & 1.13 & -0.12 & 1.01 & 0.14 & 0.47 \\
\hline France & 1.81 & 0.50 & 1.88 & 0.49 & 1.75 & 0.14 & 1.99 & 1.12 \\
\hline Germany & 1.46 & 0.12 & 1.35 & 0.51 & 1.72 & 0.30 & 1.51 & 1.04 \\
\hline
\end{tabular}

Source: Authors' computation 2017

From Table $1 \mathrm{~b}$ below, we try to juxtapose the windows by each other in the pre-and post-electoral event. The speed of reversals represented (by \% changes) shows that there is a reversal after the elections. This perhaps are the effort of regulatory agency of government to undo the pre-election effect. 
Table 1b. Descriptive statistics of macroeconomic variables and \% changes

\begin{tabular}{|c|c|c|c|c|c|c|}
\hline Country & $\begin{array}{l}\text { 3-BEF } \\
\text { Mean }\end{array}$ & $\begin{array}{l}\text { 3-AFT } \\
\text { Mean }\end{array}$ & $\% \mathrm{CHG}$ & $\begin{array}{l}\text { 12-BEF } \\
\text { Mean }\end{array}$ & $\begin{array}{l}\text { 12-AFT } \\
\text { Mean }\end{array}$ & $\% \mathrm{CHG}$ \\
\hline & \multicolumn{2}{|c|}{ For interest rate } & & & & \\
\hline$U K$ & 1.61 & 1.92 & 19 & 1.78 & 1.87 & 5 \\
\hline$U S A$ & 2.92 & 1.24 & -58 & 1.53 & 1.4 & -8.5 \\
\hline Brazil & 12.58 & 13.64 & 8.4 & 14.28 & 12.47 & -12.7 \\
\hline Egypt & 8.9 & 9.09 & 2.1 & 9.07 & 9.02 & -5.5 \\
\hline S. Africa & 7.25 & 8 & 10 & 4.84 & 9.03 & 86.6 \\
\hline Nigeria & 9.22 & 9.39 & 1.8 & 10.65 & 9.15 & -14 \\
\hline H Kong & 3.94 & 3.58 & -9 & 4.28 & 3.45 & -19 \\
\hline China & 5.87 & 6.43 & 9.5 & 6.11 & 6.22 & 1.8 \\
\hline Japan & 0.03 & 0.02 & -33 & 0.04 & 0.05 & 25 \\
\hline France & 2.83 & 2.61 & -7.8 & 2.7 & 2.81 & 4 \\
\hline \multirow[t]{2}{*}{ Germany } & 10.58 & 2 & -81 & 3.17 & 1.65 & 50 \\
\hline & \multicolumn{3}{|c|}{ For output growth } & & \multicolumn{2}{|c|}{ For output growth } \\
\hline$U K$ & 0.72 & 2.01 & 179 & -1.15 & 1.48 & 29 \\
\hline USA & -0.43 & -2.64 & -514 & 1.26 & -2.26 & -79 \\
\hline Brazil & 2.01 & 1.59 & -21 & 5.59 & 1.62 & -71 \\
\hline Egypt & 5.71 & 1.58 & -72 & -1.84 & 4.54 & 147 \\
\hline S. Africa & -4.03 & -5.21 & -29 & -1.55 & 2.62 & 69 \\
\hline Nigeria & 1.37 & 0.44 & -69 & 1.72 & -0.82 & -52 \\
\hline H Kong & -0.8 & 2.5 & 213 & 1.86 & 0.62 & -67 \\
\hline China & 14.41 & 12.41 & -16 & 15.73 & 12.11 & -23 \\
\hline Japan & -10.22 & -6.02 & 41 & -5.78 & 3.64 & 37 \\
\hline France & -0.74 & 0.18 & 76 & 0.14 & -1.01 & -621 \\
\hline \multirow[t]{2}{*}{ Germany } & -4.32 & -0.57 & 86 & -4.39 & 4.18 & 4.8 \\
\hline & \multicolumn{3}{|c|}{ For inflation } & & \multicolumn{2}{|c|}{ For inflation } \\
\hline$U K$ & 1.72 & 1.94 & 13 & 1.6 & 2.02 & 26 \\
\hline USA & 3.14 & 1.98 & -37 & 3.07 & 1.53 & -50 \\
\hline Brazil & 5.8 & 5.96 & 2.8 & 5.91 & 6.52 & 10 \\
\hline Egypt & 9.66 & 8.27 & -14.4 & 8.84 & 8.46 & -4.3 \\
\hline S. Africa & 4.92 & 5.39 & 9.6 & 6.39 & 3.37 & -47 \\
\hline Nigeria & 8.93 & 7.93 & -11 & 9.46 & 8.77 & -7.3 \\
\hline H Kong & 2.63 & 2.59 & -1.5 & 2.68 & 2.51 & -6.3 \\
\hline China & 4.73 & 4.5 & -4.9 & 4.16 & 3.33 & -20 \\
\hline Japan & -0.91 & -0.12 & 87 & -0.17 & 0.14 & 17.6 \\
\hline France & 1.81 & 1.75 & -3.3 & 1.88 & 1.99 & 5.9 \\
\hline Germany & 1.46 & 1.72 & 18 & 1.35 & 1.51 & 11.9 \\
\hline
\end{tabular}

Source: Authors' computation 2017 
Table 1c below shows the effect of the events in one year pre-and post-election development in the various macroeconomic determinants. From the table, there is a trend with some showing U-shaped and others Bell-shaped. Here, nations with weak institutions and those with relatively strong institutions can be deduced.

Table 1c. Descriptive statistics of macroeconomic variables and \% changes

\begin{tabular}{|c|c|c|c|c|c|c|}
\hline Country & $\begin{array}{l}\text { 12-BEF } \\
\text { Mean }\end{array}$ & $\begin{array}{l}\text { 3-BEF } \\
\text { Mean }\end{array}$ & $\% \mathrm{CHG}$ & $\begin{array}{l}\text { 3-AFT } \\
\text { Mean }\end{array}$ & $\begin{array}{l}\text { 12-AFT } \\
\text { MEAN }\end{array}$ & $\% \mathrm{CHG}$ \\
\hline \multicolumn{7}{|c|}{ For interest rate } \\
\hline$U K$ & 1.78 & 1.61 & -9.55056 & 1.92 & 1.87 & -2.6738 \\
\hline USA & 1.53 & 2.92 & 90.84967 & 1.24 & 1.4 & 11.4286 \\
\hline Brazil & 14.28 & 12.58 & -11.9048 & 13.64 & 12.47 & -9.3825 \\
\hline Egypt & 9.07 & 8.9 & -1.87431 & 9.08 & 9.02 & -0.66519 \\
\hline S. Africa & 4.84 & 7.25 & 49.79339 & 8 & 9.03 & 11.4064 \\
\hline Nigeria & 10.65 & 9.22 & -13.4272 & 9.39 & 9.15 & -2.62295 \\
\hline H Kong & 4.28 & 3.94 & -7.94393 & 3.58 & 3.45 & -3.7681 \\
\hline China & 6.11 & 5.87 & -3.92799 & 6.43 & 6.22 & -3.3762 \\
\hline Japan & 0.04 & 0.03 & -25 & 0.02 & 0.05 & 60 \\
\hline France & 2.7 & 2.83 & 4.814815 & 2.61 & 2.81 & 7.117 \\
\hline Germany & 3.17 & 10.58 & 233.7539 & 2 & 1.65 & -21.212 \\
\hline \multicolumn{5}{|c|}{ For output growth } & \multicolumn{2}{|c|}{ For output growth } \\
\hline$U K$ & -1.15 & 0.72 & 162.609 & 2.01 & 1.48 & -35.8108 \\
\hline$U S A$ & 1.26 & -0.43 & -134.127 & -2.64 & -2.26 & 16.814 \\
\hline Brazil & 5.59 & 2.01 & -64.0429 & 1.59 & 1.62 & 1.85185 \\
\hline Egypt & -1.84 & 5.71 & 410.326 & 1.58 & 4.54 & 65.1982 \\
\hline S. Africa & -1.55 & -4.03 & -160 & -5.21 & 2.62 & 298.855 \\
\hline Nigeria & 1.72 & 1.37 & -20.3488 & 0.44 & -0.82 & -153.659 \\
\hline H Kong & 1.86 & -0.8 & -143.011 & 2.5 & 0.62 & -303.226 \\
\hline China & 15.73 & 14.41 & -8.39161 & 12.41 & 12.11 & -2.47729 \\
\hline Japan & -5.78 & -10.22 & 76.81661 & -6.02 & 3.64 & 265.385 \\
\hline France & 0.14 & -0.74 & -628.571 & 0.18 & -1.01 & -117.822 \\
\hline Germany & -4.39 & -4.32 & 1.59453 & -0.57 & 4.18 & 113.636 \\
\hline \multicolumn{4}{|c|}{ For inflation } & & \multicolumn{2}{|c|}{ For inflation } \\
\hline$U K$ & 1.6 & 1.72 & 7.5 & 1.94 & 2.02 & -3.9604 \\
\hline$U S A$ & 3.07 & 3.14 & 2.28013 & 1.98 & 1.53 & -29.4118 \\
\hline Brazil & 5.91 & 5.8 & -1.86125 & 5.96 & 6.52 & 8.58896 \\
\hline Egypt & 8.84 & 9.66 & 9.276018 & 8.27 & 8.46 & 2.24586 \\
\hline S. Africa & 6.39 & 4.92 & -23.0047 & 5.39 & 3.37 & -59.9407 \\
\hline Nigeria & 9.46 & 8.93 & -5.60254 & 7.93 & 8.77 & 9.57811 \\
\hline H Kong & 2.68 & 2.63 & -1.86567 & 2.59 & 2.51 & -3.18725 \\
\hline China & 4.16 & 4.73 & 13.70192 & 4.5 & 3.33 & -35.135 \\
\hline Japan & -0.17 & -0.91 & 435.2941 & -0.12 & 0.14 & 185.714 \\
\hline France & 1.88 & 1.81 & -3.7234 & 1.75 & 1.99 & 12.0603 \\
\hline Germany & 1.35 & 1.46 & 8.148148 & 1.72 & 1.51 & -13.9073 \\
\hline
\end{tabular}

Source: Authors' computation 2017

From these analyses above, countries with higher output levels for the 3 months before and less after elections indicates that effort may have been put in place to ensure such improved output performance in order to enhance the 
position of the incumbent before electorates. For 12 months after elections, average output growth did not follow a reasonable pattern for the countries. Just like the interest rate case, some countries had higher growth rates 3 months before elections and others had lower growth rates. Comparing the growth rates for within the periods, it can be seen that the average growth rates of output was fairly low in the 3 months before elections period, compared with 12 months period for most of the countries. In the same vein, the growth rates were lower in the 3 months just after elections compared with 12 months after the elections. Apparently, output growth generally tends to fall during the period just before and just after elections in the sampled countries. This is perhaps connected with high costs of reversal resulting in pre-election deterioration in aggregate economic activity theory called reverse electoral business cycle. This is motivated by investment delay determined by size of policy differences between the contending political parties.

In terms of the opportunistic political cycle theory, this arrangement implies that the inflation rate was left unattended to by the monetary policy authorities during the period just before the elections in order to focus on improving the output levels. Stimulating output through lower interest rates could have had the side-effects of increasing the inflation rates. But the Central Banks are not interested in rising prices at the stage of the electioneering period as long as output growth is improving (see Hayo \& Hefeker, 2008; Masciandaro \& Tabellini, 1991).

Below is the tabular performances of the variables for the selected country to the electoral windows. Tables $1 \mathrm{a}$ and $1 \mathrm{~b}$ above were replicated in Table $1 \mathrm{~d}$ below for clarity.

Table 1d. Macroeconomic variables of countries reaction to electoral window

\begin{tabular}{|c|c|c|}
\hline INFLATION RATE & HIGH & LOW \\
\hline 3-months pre & $\begin{array}{l}\text { USA, Egypt, China, Nigeria, } \\
\text { Hong Kong, France }\end{array}$ & $\begin{array}{l}\text { UK, Brazil, South Africa, Japan, } \\
\text { Germany }\end{array}$ \\
\hline 3-months post & $\begin{array}{l}\text { UK, Brazil, Japan, South Africa, } \\
\text { Germany }\end{array}$ & $\begin{array}{l}\text { USA, Egypt, China, Nigeria, } \\
\text { Hong Kong, France }\end{array}$ \\
\hline 12-months pre & $\begin{array}{l}\text { USA, Egypt, South Africa, } \\
\text { Nigeria, Hong Kong, China }\end{array}$ & $\begin{array}{l}\text { UK, Brazil, China, Japan, } \\
\text { France, Germany }\end{array}$ \\
\hline 12-months post & $\begin{array}{l}\text { UK, Brazil, Japan, France, } \\
\text { Germany }\end{array}$ & $\begin{array}{l}\text { USA, Egypt, South Africa, } \\
\text { Nigeria, Hong Kong, China }\end{array}$ \\
\hline INTEREST RATE & HIGH & LOW \\
\hline 3-months pre & $\begin{array}{l}\text { USA, Hong Kong, Japan, } \\
\text { France, Germany }\end{array}$ & $\begin{array}{l}\text { UK, Brazil, China, Egypt, South } \\
\text { Africa, Nigeria }\end{array}$ \\
\hline 3-months post & $\begin{array}{l}\text { UK, Brazil, China, Egypt, South } \\
\text { Africa, Nigeria }\end{array}$ & $\begin{array}{l}\text { USA, Hong Kong, Japan, } \\
\text { France, Germany }\end{array}$ \\
\hline 12-months pre & $\begin{array}{l}\text { USA, Brazil, Nigeria, Hong } \\
\text { Kong, Germany, Egypt }\end{array}$ & $\begin{array}{l}\text { UK, South Africa, China, Japan, } \\
\text { France }\end{array}$ \\
\hline 12-months post & $\begin{array}{l}\text { UK, South Africa, China, Japan, } \\
\text { France }\end{array}$ & $\begin{array}{l}\text { USA, Brazil, Nigeria, Hong } \\
\text { Kong, Germany, Egypt }\end{array}$ \\
\hline OUTPUT GAP & HIGH & LOW \\
\hline 3-months pre & $\begin{array}{l}\text { USA, South Africa, Egypt, } \\
\text { Nigeria, China, Germany }\end{array}$ & $\begin{array}{l}\text { UK, Japan, France, Hong Kong, } \\
\text { Brazil }\end{array}$ \\
\hline 3-months post & $\begin{array}{l}\text { UK, Hong Kong, Japan, France, } \\
\text { Germany }\end{array}$ & $\begin{array}{l}\text { USA, South Africa, Brazil, } \\
\text { Egypt, Nigeria, China }\end{array}$ \\
\hline 12-months pre & $\begin{array}{l}\text { USA, Brazil, Nigeria, Hong } \\
\text { Kong, China, France }\end{array}$ & $\begin{array}{l}\text { UK, South Africa, Egypt, Japan, } \\
\text { Germany }\end{array}$ \\
\hline 12-months post & $\begin{array}{l}\text { UK, South Africa, Egypt, Japan, } \\
\text { Germany }\end{array}$ & $\begin{array}{l}\text { USA, Brazil, Nigeria, Hong } \\
\text { Kong, China, France }\end{array}$ \\
\hline
\end{tabular}

Source: Authors' computation 2017

Below are charts for the various windows for the selected countries which further reveal the relationship of election on the key macroeconomic variables within the time frame. 


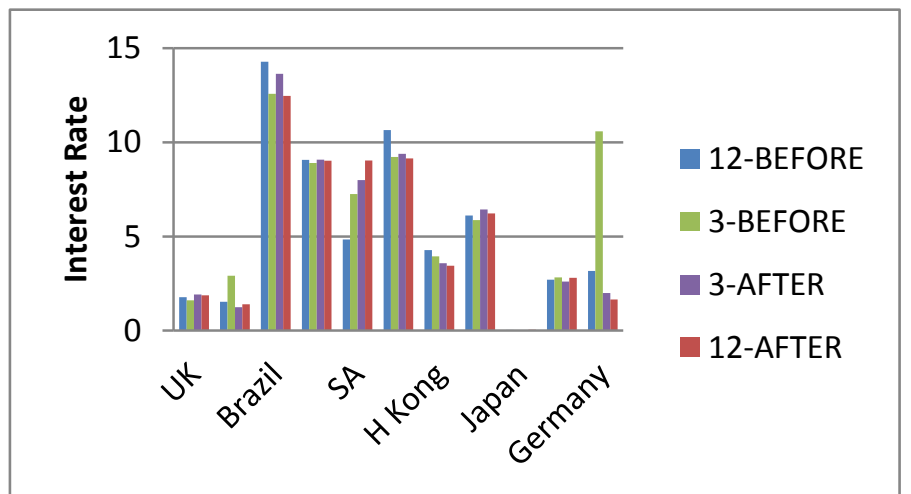

Figure 1a. Interest rate for 12-months before, 3-months before, 3-months after and 12-months after Source: Authors' computation 2017

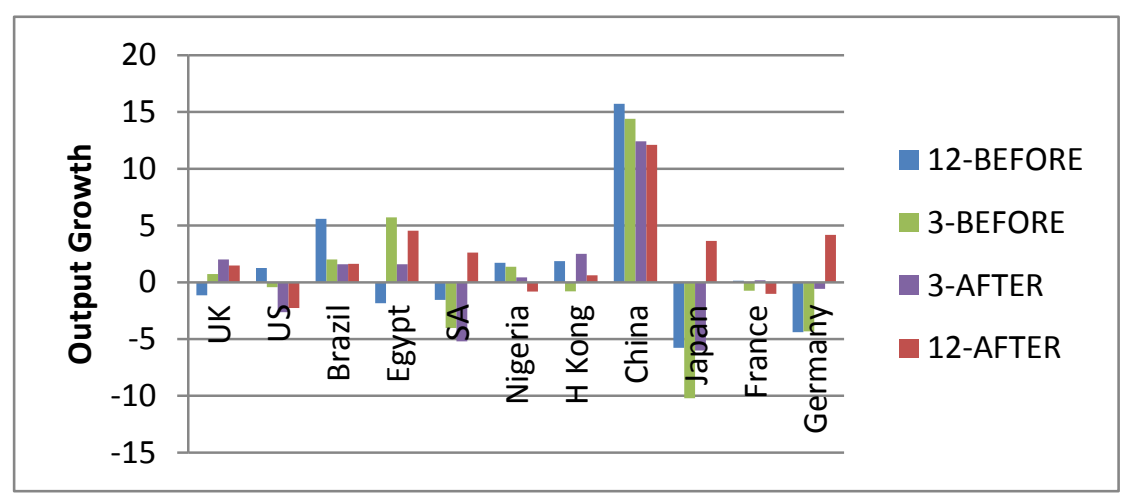

Figure 1b. Output growth for 12-months before, 3-months before, 3-months after and 12-months after Source: Authors' computation 2017

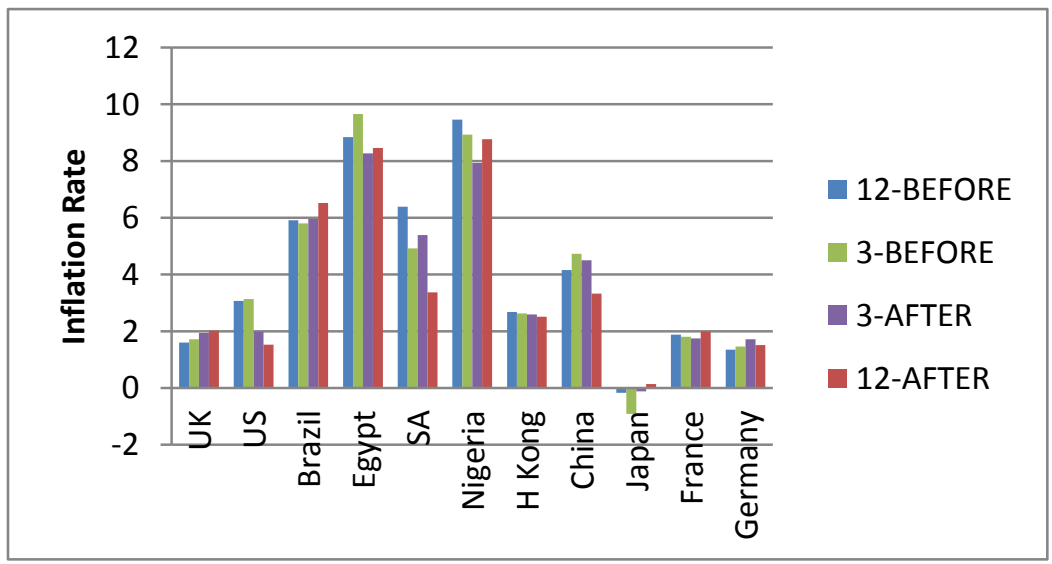

Figure 1c. Inflation rate for 12-months before, 3-months before, 3-months after and 12-months after Source: Authors' computation 2017

From charts 1a-1c, the directional movement in various indices for measuring the health of national economies is significant. To us, the comovement is in consonance with the two-opposing philosophy of the electorates and the elected officeholders. The voters' goals are determined by the current development of the economic parameters, 
geared towards their latest experience of the maniupulated macroeconomic data from government. The goal of political party in power stems from its perception and belief in voters decaying and short memory (Nordhaus, 1975 \& 1989)

\section{Style of Governance, Partisanship and Market Returns}

The working hypotheses of this study also investigated the effects of partisanship on the stock market position and returns. The results in Table 2 below with high $\mathrm{R}^{2}$ values show that the estimations captured the relationships quite well. The estimations were performed only for the countries where the required information is available. In the results, the coefficients of the party orientation were negative for the US, China, France and Germany, but it was positive (indicative of party effect) for Nigeria and Egypt. This indicates that election expectations in the market are more positive in African countries than in the more advanced markets (less in US and China and negligible in France and Germany).

Table 2. Parties and stock returns

\begin{tabular}{|c|c|c|c|c|c|c|c|c|c|c|c|c|}
\hline \multirow{2}{*}{ Variable } & \multicolumn{2}{|l|}{ US } & \multicolumn{2}{|l|}{ Egypt } & \multicolumn{2}{|l|}{ Nigeria } & \multicolumn{2}{|l|}{ China } & \multicolumn{2}{|l|}{ France } & \multicolumn{2}{|c|}{ Germany } \\
\hline & Coef. & $T$ & Coef. & $T$ & Coef. & $T$ & Coef. & $T$ & Coef. & $T$ & Coef. & $T$ \\
\hline$L W$ & $-0.07 *$ & $\begin{array}{l}-2.25 \\
(0.03)\end{array}$ & $0.88 *$ & $\begin{array}{l}2.32 \\
(0.00)\end{array}$ & $3.85^{*}$ & $\begin{array}{l}2.87 \\
(0.00)\end{array}$ & -0.08 & $\begin{array}{l}-0.33 \\
(0.74)\end{array}$ & $-0.98^{*}$ & $\begin{array}{l}-2.04 \\
(0.04)\end{array}$ & $-2.25 * *$ & $\begin{array}{l}-4.41 \\
(0.00)\end{array}$ \\
\hline$R W$ & $-0.07 * *$ & $\begin{array}{l}-3.21 \\
(0.00)\end{array}$ & $0.89 *$ & $\begin{array}{l}2.44 \\
(0.02)\end{array}$ & $4.29 * *$ & $\begin{array}{l}3.38 \\
(0.00)\end{array}$ & -0.07 & $\begin{array}{l}-0.28 \\
(0.78)\end{array}$ & $-0.99 *$ & $\begin{array}{l}-2.07 \\
(0.04)\end{array}$ & $-2.25 * *$ & $\begin{array}{l}-4.36 \\
(0.00)\end{array}$ \\
\hline$W I$ & $1.01 * *$ & $\begin{array}{l}39.4 \\
(0.00)\end{array}$ & -0.05 & $\begin{array}{l}-0.97 \\
(0.33)\end{array}$ & -0.27 & $\begin{array}{l}1.50 \\
(0.14)\end{array}$ & 0.04 & $\begin{array}{l}1.16 \\
(0.25)\end{array}$ & $1.20 * *$ & $\begin{array}{l}21.6 \\
(0.00)\end{array}$ & $1.35^{* *}$ & $\begin{array}{l}23.2 \\
(0.00)\end{array}$ \\
\hline$L S P(-1)$ & 0.00 & $\begin{array}{l}0.46 \\
(0.64)\end{array}$ & $0.92 * *$ & $\begin{array}{l}43.1 \\
(0.00)\end{array}$ & $0.96 * *$ & $\begin{array}{l}33.8 \\
(0.00)\end{array}$ & $0.94 * *$ & $\begin{array}{l}33.6 \\
(0.00)\end{array}$ & -0.06 & $\begin{array}{l}-1.49 \\
(0.14)\end{array}$ & -0.02 & $\begin{array}{c}-0.52 \\
(0.61)\end{array}$ \\
\hline$R-s q$. & 0.99 & & 0.94 & & 0.92 & & 0.95 & & 0.98 & & 0.98 & \\
\hline
\end{tabular}

P-values are in parenthesis

Source: Authors' computations 2017

The specific focus of the analysis is on the signs of the coefficients for the party orientations (either incumbent or opposition). A partisanship effect is recognized if the coefficients for the variables are different either in signs, size or significance. From the results in the above table, the coefficients of the partisanship effects have the same signs for each of the countries and significant except for Nigeria and Egypt. Also, the coefficients are similar in terms of size. Hence, the results show that the party orientation does have significant impact on stock market returns for the selected countries except for Nigeria and Egypt.

\section{Conclusion, Policy Implication and Recommendations}

In the light of the results from the analysis above, the study therefore provides conclusive evidnce of the existence of a significant relationship between national economic performance data and electoral cycles in countries of the world irrespective of their developmental stages and institutional setting. There is also evidence that since Central Banks are not interested in rising prices during electioneering period, given improvments in outputs, electorates fall into the trap set by political actors (Hayo and Hefeker, 2008; Masciandaro and Tabellini, 1991). This comovement appears to support the two opposing philosophies of the electorates and the elected officeholders. The voters' goals of assessing performances by current development in the economic parameters arising from what they have received lately from government agencies as well as incumbent governments' goalsin manipulation originating from their perception and belief in voters decaying and forgetful memory.

On the other hand, the study also shows that monetary authorities tend to integrate incumbent government objectives and vision to winning elections into their regulatory policies. This they do by guaranteeing favourable 
macroeconomic indicators for the period before the elections. More importantly, the result of the analysis shows that political activities' effects on output and inflation tend to vary within a dynamic structure. This implies that policy aimed at influencing these factors should be tailored along short term and long term effective policy making for the ever- changing dynamics of modern financial system.

As a policy recommendation, there is need to take cognizance of the lag effect in the design of financial and monetary policies in order to ensure that their targets are effectively monitored. In particular, monetary policies need to be forward looking in their approach to address real sector development in the countries examined. This may explain why some investment rules and regulations may not be sufficient for modern day competitive global business. Therefore, we call for a better integration between financial and economic data into the political framework to ensure genuine devlopment. We recommend the automation of capital market activities aimed at bridging information asymmetry among market participants as well as institutional strengthening of all government agencies in charge of macro-economic data and capital markets to avoid easy manipulation of one by another.

\section{References}

Acemoglu, D., \& Yared, P. (2010). Political limits to globalization. NBER working paper, 15694. https://doi.org/10.3386/w15694

Akhmedov, A., \& Zhuravskaya, E. (2004). Opportunistic political cycles: Test in a young democracy setting. Quarterly Journal of Economics, 119, 1301-1338. https://doi.org/10.1162/0033553042476206

Andrikopoulos, A., Ioannis L., \& Prodromidis, K. (2004). Fiscal policy and political business cycles in the EU. European Journal of Political Economy, 20(1), 125-152. https://doi.org/10.1016/j.ejpoleco.2003.02.001

Asutay, M. (2004). Searching for opportunistic political business cycles in Turkey. Annual Conference of the European Public Choice Society, Berlin.

Blomberg, S.B., \& Hess, G.D. (2003). Is the political business cycle for real?. Journal of Public Economics, 8, 1091-1121. https://doi.org/10.1016/S0047-2727(01)00142-6

Brunner, M. (2009). Does politics matter? The influence of elections and government formation in the Netherlands on the Amsterdam exchange index. Acta Politica, 44(2), 150-170. https://doi.org/10.1057/ap.2008.37

Cerda, R., \& Vergara, R. (2007). Business cycle and political election outcomes: Evidence from the Chilean democracy. Public Choice, 132, 125-136. https://doi.org/10.1007/s11127-006-9138-5

Drazen, A. (2000). The AFPM model of the political business cycle. Working paper, 2000.

Drazen, A., \& Eslava, M. (2010). Electoral manipulation via voter-friendly spending: theory and evidence. Journal of Development Economics, 92(1), 39-52. https://doi.org/10.1016/j.jdeveco.2009.01.001

Eboigbe, S.U. (2016). Political Events, Capital Markets and Economic Performances of selected Countries, PhD Thesis, University of Benin, Nigeria.

Fang, L., \& Silos, P. (2012). Wages and unemployment across business cycles: A High-frequency investigation. Federal Reserve Bank of Atlanta. Working paper 16. https://doi.org/10.2139/ssrn.2479462

Findley, T.S. (2015). Hyperbolic memory discounting and the political business cycle. Retrieved from http://ssrn.com/abstract=2518188 https://doi.org/10.1016/j.ejpoleco.2015.08.002

Foremny, D., \& Riedel, N. (2014). Business taxes and the electoral cycle. Journal of Public Economics, 115, 48-61.

Franzese, R. J. (2002). Electoral and partisan cycles in economic policies and outcomes. Annual Review of Political Science 5, 369-421.

Furio, M. D., \& Pardo, A. (2010). Politics and elections at the Spanish stock market. University of Valencia Working Paper, 11 .

Furio, D., \& Pardo, A. (2012). Partisan politics theory and stock market performance: Evidence for Spain. Revista española de financiacióny contabilidad, 61(155), 371-392.

Garcia-Sanchez, I.M., Mordan, N., \& Cuadrado-Ballesteros, B. (2014). Do electoral cycles affect local financial health?. Policy Studies, 35, 533-556. https://doi.org/10.1080/01442872.2014.971727

Gerber, A. S., Huber, G.A., \& Washington, E. (2009). Party affiliation, partisanship, and political beliefs: A field experiment. NBER working paper, 15365. https://doi.org/10.3386/w15365 
Goodell, J. W., \& Bodey, R. A. (2012). Price-earnings changes during US presidential election cycles: Voter uncertainty and other determinants. Public Choice, 150, 633-650. https://doi.org/10.1007/s11127-010-9720-8

Haynes, S. E., \& Stone, J.A. (1989). Political models of the business cycle should be reviewed. Economic Inquiry, 28, 442-465. https://doi.org/10.1111/j.1465-7295.1990.tb01233.x

He, Y., Lin, H., Wu, C., \& Dufrene, U.B. (2009). The 2000 presidential election and the information cost of sensitive versus non-sensitive S\&P500 stocks. Journal of Financial Markets, 12(1), 54-86. https://doi.org/10.1016/j.finmar.2008.04.004

Iyoha, M.A., Oyefusi, S.A., \& Oriakhi, D.E. (2003). An introduction to modern macroeconomics (revised edition). Mindex publishing, Nigeria.

Jones, A.T., \& Snyder, M.W. (2014). Federal Reserve independence: the Fed funds rate under different regimes. Applied Economics Letters, 21, 1262-1265. https://doi.org/10.1080/13504851.2014.920473

Kachelein, H., Imami, D., \& Lami, E. (2008). A new view into political business cycles: household expenditures in Albania. BERG working paper, 60, BAMBERG.

Karakas, M. (2014). Political business cycles in turkey: a monetary approach. Electronic Journal of Social Sciences, 13(48), 159-175 https://doi.org/10.17755/esosder.07188

Klomp, J., \& de Haan, J. (2013). Political budget cycles and election outcomes. Public Choice, 157, 245-267. https://doi.org/10.1007/s11127-012-9943-y

Klose, J. (2011). Political Business Cycles and Monetary Policy Revisited - An Application of a Two-Dimensional Asymmetric Taylor Reaction Function. Ruhr Economic Papers no 286. https://doi.org/10.2139/ssrn.1954686

Klose, J. (2011). Asymmetric Taylor Reaction Functions of the ECB: An Approach Depending on the State of the Economy. North American Journal of Economics and Finance, 22(2), 149-163. https://doi.org/10.1016/j.najef.2011.01.002

Knight, B. G. (2007). Are policy platforms capitalized into equity prices? Evidence from the Bush/Gore 2000 presidential election. Journal of Public Economics, 91(1-2), 389-409. https://doi.org/10.1016/j.jpubeco.2006.06.004

Koksal, B., \& Aliskan, A. (2012). Political business cycles and partisan politics: evidence from a developing economy. Economics \& Politics, 24(2), 182-199

Krause, G. (2005). Electoral incentives, political business cycles and macroeconomic performance: empirical evidence from post-war US personal income growth. British Journal of Political Science, 35, 77-101. https://doi.org/10.1017/S0007123405000049

Kuzu, Y. (2001). Political business cycle in the Turkish economy: 1977-2001. METU conference in economics VII on September 6-9, 2003, Ankara, Turkey.

Leblang, D., \& Mukherjee, B. (2004). Presidential elections and the stock market: comparing Markov-Switching and (FIE) GARCH models of stock volatility. Political Analysis, 12(3), 296-322. https://doi.org/10.1093/pan/mph020

Leblang, D., \& Mukherjee, B. (2005). Government partisanship, elections and the stock market: Examining American and British stock returns (1930-2000). American Journal of Political Science, 49(4), 780-802. https://doi.org/10.1111/j.1540-5907.2005.00155.x

Leertouwer, E., \& Maier, Z. (2001). Who creates political business cycles: should central banks be blamed? European Journal of Political Economy, 17, 445-463. https://doi.org/10.1016/S0176-2680(01)00040-4

Leertouwer, E., \& Maier, P. (2002). International and domestic constraints on political business cycles in OECD economies: A comment. International Organization, 56(1), 209-221. https://doi.org/10.1162/002081802753485188

Mattozzi, A. (2008). Can we insure against political uncertainty? Evidence from the U.S. Stock market. Public Choice, 137(1-2), 43-55. https://doi.org/10.1007/s11127-008-9311-0

Mukherjee, B., \& Leblang, D. (2007). Partisan politics, interest rates and the stock market: Evidence from American and British returns in the Twentieth Century. Economics and Politics, 19(2), 135-167. https://doi.org/10.1111/j.1468-0343.2007.00306.x 
Oehler, A., Walker, T.J., \& Wendt, S. (2011). Effects of election results on stock price performance: Evidence from 1976 to 2008. Working Paper. 74th International Atlantic Economic Conference, Montreal.

Overman, H.G., \& Puga, D. (2002). Unemployment Clusters across Europe's Regions and Countries. Economic Policy, 17, 115-147. https://doi.org/10.1111/1468-0327.00085

Rakic, B., Stanojevic, J., \& Rađenovic, T. (2015). Political cycles' influence on inflation and unemployment. Journal of economic institute, 43(2), 103-122. https://doi.org/10.5937/industrija43-7922

Santa-Clara, P., \& Valkanov, R. (2003). The presidential puzzle: Political cycles and the stock market. Journal of Finance, 58, 1841-1872. https://doi.org/10.1111/1540-6261.00590

Shelton, C.A. (2014). Legislative budget cycles. Public Choice, 159, 251-275. https://doi.org/10.1007/s11127-012-0043-9

Sieg, G., \& Batool, I. (2012). Pakistan, politics and political business cycles, Pakistan Development Review, 51(1), 153-166.

Siokis, F., \& Kapopoulos, P. (2007). Parties, elections and stock market volatility: Evidence from a small open economy. Economics and Politics, 19(1), 123-134. https://doi.org/10.1111/j.1468-0343.2007.00305.x

Taylor, J.B. (1993). Discretion versus rules practices. Carnegie-Rochester conference series on public policy, 39, 195-214. https://doi.org/10.1016/0167-2231(93)90009-L

Taylor, J.B. (2000a). Reassessing discretionary fiscal policy. Journal of Economic Perspectives, 14(3), 21-36. https://doi.org/10.1257/jep.14.3.21

Taylor, J.B. (2000b). Using monetary policy rules in emerging market economies, Stabilization and Monetary Policy: The International Experience, Bank Mexico, 441-457.

Tutar, I., \& Tansel, A. (2000). Political business cycles, institutional structure and budget deficits in Turkey. Paper presented in Metu Conference in Economics.

Vasquez-Ruiz, H.A., Rivas, R., \& Daz, R. (2014). Do politics determine policy? Evidence on the political-economic business cycle in the Dominican Republic. Central Bank of the Dominican Republic working paper.

Veiga, L. G., \& Veiga, F. J. (2007). Does Opportunism Pay off? Economic letters, 96(2), 177-182. https://doi.org/10.1016/j.econlet.2006.12.026

Wall, H.J., \& Zoega, G. (2002). Regional business cycles and the natural rate of unemployment. Central bank of Iceland working paper. Retrieved from http://www.sedlabanki.is

Wolfers, J., \& Zitzewitz, E. (2004). Prediction Markets. Journal of Economic Perspectives, 18(2), 107-126. https://doi.org/10.1257/0895330041371321

Wong, W., \& McAleer, M. (2009). Mapping the presidential election cycle in U.S.A stock markets. Mathematics and Computers in Simulation, 79(11), 3267-3277. https://doi.org/10.1016/j.matcom.2009.05.007

Wooldridge, J.M. (2001). Applications of Generalized Method of Moments Estimation. Journal of Economic Perspectives, 15(4), 87-100. https://doi.org/10.1257/jep.15.4.87 